\title{
A glikációs index lehetséges magyarázata a hemoglobinglikáció biokinetikus modellje alapján
}

\author{
Rácz Olivér dr. ${ }^{1,2}$ - Barkai László dr. ${ }^{2,3,4}$ - Eigner György dr. ${ }^{4,5}$ \\ Kovács Levente dr. ${ }^{4,5}$. Bicsák Melinda ${ }^{5}$ \\ Muriová Katalin dr. ${ }^{6}$ - Dombrovsky Péter dr. ${ }^{1}$ \\ ${ }^{1}$ Pavol Jozef Šafárik Egyetem, Orvostudományi Kar, Kórélettani Intézet, Kassa-Košice, Szlovákia \\ ${ }^{2}$ Miskolci Egyetem, Egészségügyi Kar, Elméleti Egészségtudományok Intézete, Miskolc \\ ${ }^{3}$ Pavol Jozef Šafárik Egyetem, Orvostudományi Kar, Gyermekgyógyászati Klinika, Kassa-Košice, Szlovákia \\ ${ }^{4}$ Óbudai Egyetem, Neumann János Informatikai Kar, Biomatika és Alkalmazott Mesterséges Intelligencia Intézet, \\ Budapest \\ ${ }^{5}$ Óbudai Egyetem, Egyetemi Kutató és Innovációs Központ, Élettani Szabályozások Kutatóközpont, Budapest \\ ${ }^{6}$ Popradi Kórház, Poprad, Szlovákia
}

\begin{abstract}
Bevezetés: $\mathrm{A} \mathrm{HbA}_{\mathrm{lc}}$ integrált retrospektív mutatója az elmúlt időszak vércukrának, rendszeres vizsgálata a cukorbetegek anyagcserekontrolljának megítélésében elengedhetetlen. Helyes értékelése azonban nem egyszerü, mert a HbA $\mathrm{l}_{\mathrm{c}}$ és a vércukor közötti összefüggés nem lineáris. A mérést közvetlenül megelőző hyperglykaemiás epizódok hatása a $\mathrm{HbA}_{1 \mathrm{c}}$ szintjére nagyobb, mint azoké, amelyek régebben történtek. A jelenségre a glikáció biokinetikus modellje ad magyarázatot.

Célkitüzés: A mért és a biokinetikus modell alapján számított $\mathrm{HbA}_{1 \mathrm{c}}$ közötti egyezés, illetve diszkordancia vizsgálata. Módszer: A vizsgálatokat 157, l-es és 2-es típusú cukorbeteg 1793, laboratóriumban mért éhomi vércukor- és 511 $\mathrm{HbA}_{\mathrm{lc}}$-adatából végeztük. A különbséget a glikációs index segítségével számítottuk, amely a mért és a számított $\mathrm{HbA}_{\mathrm{lc}}$-érték aránya.

Eredmények: Egyezést mindössze a vizsgált betegek kevesebb mint egyötödödében találtunk, 60\%-ban az index értéke alacsony $(<0,95)$ és 21\%-ban magas $(>1,05)$ volt. Az adatok részletes analízise szerint jó anyagcserekontroll esetében gyakoribb a vártnál magasabb, mért $\mathrm{HbA}_{\mathrm{lc}}$-érték, mint a biokinetikus egyenlet által számítotté, és rosszabb kontroll (magasabb átlagos vércukor) esetében ez fordítva van. Egyezés esetén a regressziós egyenlet együtthatói gyakorlatilag azonosak a modell alapján számított értékekkel.

Következtetés: Vizsgálataink felvetik azt a lehetőséget, hogy a biokinetikus modell magyarázatot adhat a vércukor és a $\mathrm{HbA}_{1 \mathrm{c}}$ közötti diszkordanciára.

Orv Hetil. 2021; 162(41): 1652-1657.
\end{abstract}

Kulcssavak: hemoglobinglikáció, $\mathrm{HbA}_{1 \mathrm{c}}$, glikációs index, biokinetikus modell, diabetes mellitus

\section{Possible explanation of the hemoglobin glycation index by the biokinetic model of glycation}

Introduction: $\mathrm{HbA}_{\mathrm{lc}}$ is an integrated retrospective marker of previous blood glucose concentrations and its regular measurement is indispensable in the assessment of glycaemic compensation of diabetic patients. However, its proper interpretation is not simple becasuse the relationship between $\mathrm{HbA}_{\mathrm{lc}}$ and average glycemia is not a linear one. Hyperglycemic episodes occuring immediately before the measurement have greater impact on the $\mathrm{HbA}_{\mathrm{lc}}$ level as compared with those taking place earlier.

Objective: Assessment of concordance and discordance between measured and according to the biokinetic model calculated values of $\mathrm{HbA}_{\mathrm{lc}}$.

Method: The calculations were made from averages of 1793 fasting blood glucose and $511 \mathrm{HbA}_{\mathrm{lc}}$ of 157 , type 1 and 2 diabetic patients. The glycation index is the quotient between measured and calculated $\mathrm{HbA}_{1 \mathrm{c}}$.

Results: Agreement was found in less than one fifth of the 157 patients; in $60 \%$ the value of glycation was low $(<0.95)$ and in $21 \%$ high $(>1.05)$. Analysis of the glycation index according to the level of glycemic compensation revealed 
that in patients with good compensation, the measured $\mathrm{HbA}_{\mathrm{lc}}$ value was more often higher than the expected and in patients with unsatisfactory compensation the opposite was true.

Conclusion: These results raise the possibility that the discordance between average glycemia and measured $\mathrm{HbA}_{\mathrm{lc}}$ can be explained by the biokinetic model.

Keywords: hemoglobin glycation, $\mathrm{HbA}_{1 \mathrm{c}}$, glycation index, biokinetic model, diabetes mellitus

Rácz O, Barkai L, Eigner Gy, Kovács L, Bicsák M, Muriová K, Dombrovsky P. [Possible explanation of the hemoglobin glycation index by the biokinetic model of glycation]. Orv Hetil. 2021; 162(41): 1652-1657.

(Beérkezett: 2021. február 6.; elfogadva: 2021. április 8.)

\section{Rövidítések}

CGM = (continuous glucose monitoring) folyamatos szövetiglükóz-monitorozás; eAG = (estimated average glucose) a mért $\mathrm{HbA}_{\mathrm{lc}}$-ból számolt átlagos vércukor; $\mathrm{G}_{\mathrm{gap}}=$ (glycation gap) glikációs rés, a várt és a mért $\mathrm{HbA}_{\mathrm{lc}}$ közötti különbség; $\mathrm{G}_{\text {index }}=$ glikációs index, a várt és a mért $\mathrm{HbA}_{\mathrm{lc}}$ aránya; $\mathrm{HbA}_{\mathrm{lc}}$ $=$ hemoglobin $-\mathrm{A}_{\mathrm{lc}}$ (glikált hemoglobin $) ; \mathrm{IFCC}=($ International Federation of Clinical Chemistry) Nemzetközi Klinikai Kémiai Szövetség; TIR = (time in range $)$ céltartományon belüli időszak

$\mathrm{A} \mathrm{HbA}_{\mathrm{lc}}$ felfedezése és mérésének széles körű alkalmazása forradalmasította a diabetológiát [1]. Az eredeti nézet szerint (amely abból indult ki, hogy az emberi vörösvérsejtek élettartama 120 nap, és a glükóz kötődése a hemoglobinhoz irreverzibilis) a $\mathrm{HbA}_{\mathrm{lc}}$ koncentrációja az előző 4 hónap átlagos vércukrának integrált retrospektív mutatója. Ez lényegében igaz, de pontatlan interpretáció. A hemoglobin glikációjának kinetikája két folyamat kombinációja. A glükóz kötődése a hemoglobinhoz egy elsőrendű reakció és a glükózkoncentráció függvénye. Ugyanakkor a vörösvérsejtek állandó sebességgel termelődnek a csontvelőben, majd 4 hónap elteltével a lép távolítja el óket. Ez egy nulladik rendú kinetika [2].

A két folyamat kombinációja azt eredményezi, hogy a $\mathrm{HbA}_{\mathrm{lc}}$ értéke jobban tükrözi a nem sokkal korábban lejátszódott vércukorérték-változásokat, mint azokat, amelyek régebben történtek (1. ábra). Ezt az utóbbi időben a gyakorlatban olyan módon veszik figyelembe, hogy a $\mathrm{HbA}_{\mathrm{lc}}$ az előző 6-8 hét átlagos vércukrát tükrözi [3], de ez az állítás nem pontos.

A jelenség magyarázata az, hogy az öreg vörösvérsejtek a keringésben az egész 120 napos időszak alatt jelen vannak, de a fiatalok csak az utolsó időben (az 1. ábrán látható modellekben ez 60 nap). Az öreg vörösvérsejtekben a $\mathrm{HbA}_{\mathrm{lc}}$ szintézise 60 napig a magasabb, 60 napig az alacsonyabb vércukornak felel meg, és mindegy, hogy a hyperglykaemiás epizód mikor történt. Az öreg vérsejtekben ezért a $\mathrm{HbA}_{\mathrm{lc}}$ szintje az átlagos $\left(7,5 \mathrm{mmol} \cdot \mathrm{l}^{-1}\right)$ vércukornak felel meg mind a két modellben. A fiatal vörösvérsejtek azonban különböző vércukor-koncentráció esetében vannak jelen a vérben, ezért a $\mathrm{HbA}_{\mathrm{lc}}$ magasabb az „A" modellben (vércukor: 10,0 mmol. ${ }^{-1}$ ), mint a „B” modellben (vércukor: 5,0 mmol.1 ${ }^{-1}$ ). A méréshez levett vérben az öreg és a fiatal vörösvérsejtek egyforma arányban vannak jelen, és a két modell közötti különbséget a fiatal vörövérsejtek eltérő $\mathrm{HbA}_{\mathrm{lc}}$-szintje $(\mathrm{A}>\mathrm{B})$ adja meg.

A mindennapi diabetológiai gyakorlatban nem fordulnak elő olyan hosszan tartó időszakok, mint az ábrázolt modellekben, de igaz az a következtetés, hogy a $\mathrm{HbA}_{\mathrm{lc}}$ szintje jobban tükrözi a nem sokkal korábban lejátszódott hyperglykaemiát, mint azokat, amelyek régebben történetek. A jelenséget „retrospektív torzításként” is le lehet írni.

A glikáció matematikai modellezését először 1979ben írta le Beach [4]; az általa leírt egyenletek lehetővé tették a $\mathrm{HbA}_{\mathrm{lc}}$ koncentrációjának kiszámolását állandó vércukorértékek mellett (2. ábra) és abban az esetben, ha a beteg vércukra hosszabb ideig megváltozott (a rövid ideig tartó ingadozások nem befolyásolják a $\mathrm{HbA}_{1 \mathrm{c}}{ }^{-\mathrm{t}}$ ). A biokinetikus modell érvényességét és létjogosultságát mások is alátámasztották $[5,6]$, de módszer a gyakorlat-

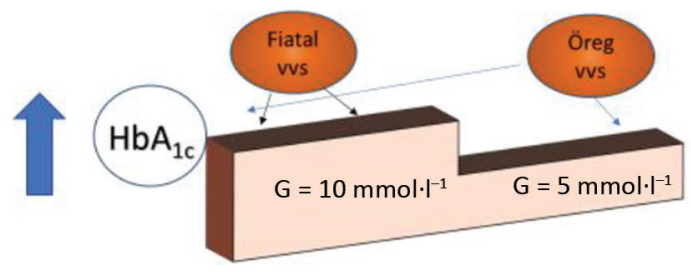

A

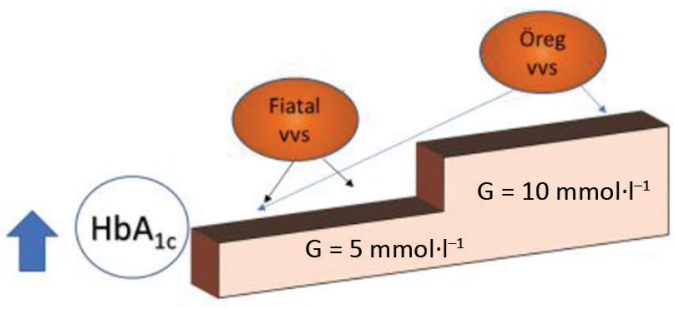

B

$\mathrm{HbA}_{1 \mathrm{c}}, \mathrm{A}^{\prime \prime}>\mathrm{HbA}_{1 \mathrm{c}}, \mathrm{B}^{\prime \prime}$

1. ábra $\quad$ A különböző időben történt hyperglykaemiás epizódok modelljei A nem sokkal korábban lejátszódott hyperglykaemia jobban hat a $\mathrm{HbA}_{\mathrm{lc}}$ szintjére, mint az, amelyik régebben történt. A két modell átlagos vércukra azonos $\left(7,5 \mathrm{mmol} \cdot \mathrm{l}^{-1}\right)$, a számított $\mathrm{HbA}_{1 \mathrm{c}}$ az "A" esetben 77,0 , a „B” esetben $49,0 \mathrm{mmol} \cdot \mathrm{mol}^{-1}$

$\mathrm{HbA}_{\mathrm{lc}}=$ hemoglobin- $\mathrm{A}_{\mathrm{lc}}$ (glikált hemoglobin $) ; \mathrm{vvs} \mathrm{=} \mathrm{vörösvérsejt}$ 
ban nem terjedt el. Ennek oka egyrészt az egyenletek bonyolultsága volt, másrészt az, hogy a gyakorló diabetológusoknak nem állt rendelkezésükre elég adat a múltban lejátszódott, hosszan tartó vércukor-ingadozásokról. Amennyiben a vércukor és a $\mathrm{HbA}_{\mathrm{lc}}$ értékei között ellentmondás volt, akkor az volt a nézet, hogy a $\mathrm{HbA}_{\mathrm{lc}}$ ad pontosabb információt az anyagcserekontrollról, mert az integrált mutató, a vércukor értéke pedig csak pillanatkép [7].

A helyzet mára a folyamatos szövetiglükóz-monitorozás (CGM - continuous glucose monitoring) elterjedésével és az abból számolt mutatók bevezetésével megváltozott: ezek pontosabban tükrözik a beteg vércukorkontrollját, mint a bizonyos időpontokban laboratóriumban vagy otthon mért értékek. A CGM-vércukorértékekből számolt egyik legfontosabb mutató a „céltartományon belüli idószak (time in range - TIR)", amely szerint a vércukor szintje a vizsgált idôszak 70\%-ában 3,9-10,0 mmol. $\mathrm{l}^{-1}$ között kell, hogy legyen. Ez egy napra számolva 16 óra 45 perc. Amennyiben az eredmények az elvárt céltartományon belül vannak, akkor a $\mathrm{HbA}_{\mathrm{lc}}$ mért eredményének az 1 . táblázatban megadott "jó" vagy „elfogadható” tartományban kell lennie [8].

Az új, integrált mutatók azonban nem küszöbölték ki azt a problémát, amelyek a mindennapi gyakorlatban merülnek fel - a $\mathrm{HbA}_{1 c}$ szintje gyakran nem felel meg a vércukorértékeknek, és az ellentmondást nem lehet az ismert zavaró tényezók [9] segítségével (2. táblázat) megmagyarázni. A vércukor és a $\mathrm{HbA}_{1 \mathrm{c}}$ közötti diszkordancia jelenségét számszerúleg két módon lehet megadni. A glikációs rés (glycation gap, $\mathrm{G}_{\mathrm{gap}}$ ) a mért $\mathrm{HbA}_{\mathrm{lc}}$ és az átlagos vércukor alapján számolt $\mathrm{HbA}_{1 c}$ közötti különbség, és a glikációs index $\left(\mathrm{G}_{\text {index }}\right)$ a két adat hányadosa. $A_{\mathrm{g}_{\mathrm{gap}}}$ és a $\mathrm{G}_{\text {index }}$ meghatározásához az átlagos vércukorértékekből regressziós egyenletek alapján lehet a $\mathrm{HbA}_{\mathrm{lc}}$ várt értékét kiszámolni. Ha a két adat egyezik, a rés értéke 0, az indexé 1,0 [10-13].

1. táblázat | $\mathrm{A} \mathrm{HbA}_{1 \mathrm{c}}$ értékei különböző szintű anyagcserekontrollok eseté ben

\begin{tabular}{lll}
\hline Anyagcserekontroll & $\begin{array}{l}\text { IFCC-egységek } \\
\mathrm{mmol} \cdot \mathrm{mol}^{-1}\end{array}$ & $\begin{array}{l}\text { DCCT-egységek } \\
\mathrm{Hb} \%\end{array}$ \\
\hline Jó (good) & $<43$ & $<6,0$ \\
$\begin{array}{l}\text { Elfogadható } \\
\text { (satisfactory) }\end{array}$ & $44-60$ & $6,0-7,5$ \\
$\begin{array}{l}\text { Nem megfelelő } \\
\text { (unsatisfactory) }\end{array}$ & $61-75$ & $7,6-9,0$ \\
Rossz (bad) & $>75$ & $>9,0$ \\
\hline
\end{tabular}

A DCCT-egységek átszámítása az IFCC-egységekre a $\mathrm{HbA}_{\mathrm{lc}\left[\mathrm{mmol} \cdot \mathrm{mol}^{-1}\right]}$ $=\mathrm{HbA}_{\mathrm{lc}[\%]}$ * 10,93-23,5 egyenlet alapján lehetséges.

A táblázat adatai az ADA 2019-es irányelveinek [16] felelnek meg.

$\mathrm{ADA}=$ Amerikai Diabetes Társaság; $\mathrm{DCCT}=($ Diabetes Control and Complication Trial) a cukorbetegség elleni védekezés és szövődményvizsgálat; $\mathrm{HbA}_{\mathrm{lc}}=$ hemoglobin- $\mathrm{A}_{\mathrm{lc}}$ (glikált hemoglobin); $\mathrm{IFCC}=$ Nemzetközi Klinikai Kémiai Szövetség

\section{Célkitüzés}

Saját megfigyeléseink alapján meghatároztuk a $\mathrm{G}_{\text {index }}$ értékeit, és ezeket összehasonlítottuk a mért $\mathrm{HbA}_{\mathrm{lc}}$-értékekkel. A munka második részében ismertetjük a biokinetikus modellt, majd arra a kérdésre kísérelünk meg választ adni, hogy lehetséges-e az átlagos vércukor és a $\mathrm{HbA}_{\mathrm{lc}}$ közötti diszkordanciát megmagyarázni a glikáció biokinetikus modelljével.

\section{Betegek és módszerek}

A vizsgálatba 157 , ambulánsan kezelt cukorbeteget $(37$ l-es és 120 2-es típus) vontunk be. A 2-es típusú cukorbetegek közül 34-en voltak kezelve inzulinnal, a többiek (86 személy) orális készítményekkel. A vizsgálatba csak diétával kezelt betegeket nem vontunk be, és az inzulinnal kezeltek közül egy sem használt pumpát. Adataik a 3. táblázatban szerepelnek.

A 157 betegnél összesen 1793 vércukormérés történt, ami a 30,8 hónapos (12-51 hónap határértékek) átlagos követési idôt figyelembe véve évi 670 mérésnek felelt meg. Ezek mind laboratóriumi éhomi mérések voltak. A minimum évi mérések határértékei 2 és 31 között voltak. A HbA ${ }_{1 c}$-mérések (összesen 511 mérés) egy laboratóriumban történtek immunkémiai módszerrrel, Cobas C6000 automatikus analizátoron Tina-quant $\mathrm{HbA}_{\mathrm{lc}}$ (Roche, Bázel, Svájc) turbidimetriás módszerrel.

A vizsgált betegcsoportban nem fordult elő olyan bizonyított zavaró tényező, amely hibás eredményhez vezethet. Egy 'outlier' adatot (vércukor 19,3 mmol.1-1; az ehhez tartozó $\left.\mathrm{HbA}_{\mathrm{lc}} 55,8 \mathrm{mmol} \cdot \mathrm{mol}^{-1}\right)$ a további számításokban nem vettünk figyelembe, mert vagy mérési

2. táblázat |Zavaró tényezők, melyek hamis $\mathrm{HbA}_{1 \mathrm{c}}$-értékekhez vezetnek

Bizonyitottak

A vörösvérsejtek élettartamának csökkenése (alacsonyabb HbA a vártnál)

Abnormális hemoglobinok jelenléte (értékelhetetlen eredmény az egészséges heterozigótákban is)

Fetalis hemoglobin felnőttkorban (értékelhetetlen eredmény, a HbF-nek nincs béta-lánca, amelyhez a glükóz kötődne)

\section{Nem egyértelmüen bizonyitottak, vitatottak}

A $\mathrm{HbA}_{\mathrm{lc}}$ deglikációja fruktózamin-3-kináz enzim hatására (alacsonyabb $\mathrm{HbA}_{\mathrm{lc}}$ a vártnál)

A GLUTl glükóztranszporter csökkent kapacitása a vörösvérsejtekben (alacsonyabb $\mathrm{HbA}_{\mathrm{lc}}$ a vártnál)

Nem bizonyitottak, jelenleg nincs jelentóségük a mindennapi diabetológiában

Vashiányos anaemia (alacsonyabb $\mathrm{HbA}_{\mathrm{lc}}$ a vártnál?)

Etnikai csoportok közötti különbségek (?)

Életkor (?)

Táplálkozási szokások és túlzott alkoholfogyasztás (?)

$\mathrm{HbA}_{\mathrm{lc}}=$ hemoglobin-A $\mathrm{lc}_{\mathrm{c}}$ (glikált hemoglobin $)$ 
3. táblázat |A vizsgált betegek adatai

\begin{tabular}{|c|c|c|}
\hline Mutató & $\begin{array}{l}\text { Esetszám, } \\
\text { illetve minimum- } \\
\text { maximum }\end{array}$ & $\begin{array}{l}\text { Százalék, } \\
\text { illetve átlag }\end{array}$ \\
\hline Vizsgált betegszám & 157 & \\
\hline Férfiak/nők & $61 / 96$ & $38,6 / 61,4$ \\
\hline 1-es/2-es típus & $37 / 120$ & $23,4 / 76,6$ \\
\hline $\begin{array}{l}\text { Gyógykezelés } \\
\text { Inzulin/oralis }\end{array}$ & $71 / 86$ & $45,2 / 54,8$ \\
\hline Életkor, év & $20-89$ & 65 \\
\hline A megfigyelés időtartama, év & $1-4,2$ & 2,57 \\
\hline Vécukormérés, összesen & 1793 & \\
\hline Vércukormérés, évenként & $1-9$ & 4,2 \\
\hline $\mathrm{HbA}_{\mathrm{lc}}$-mérés, összesen & 511 & \\
\hline $\mathrm{HbA}_{\mathrm{lc}}$-mérés, évenként & $0,25-4,81$ & 1,51 \\
\hline
\end{tabular}

$\mathrm{HbA}_{\mathrm{lc}}=$ hemoglobin- $\mathrm{A}_{\mathrm{lc}}$ (glikált hemoglobin $)$

hiba, vagy fel nem derített zavaró tényező következménye volt. A mért adatokat a biokinetikus modell $\{1\}$ alapján számolt $\mathrm{HbA}_{\mathrm{lc}}$-adatokkal hasonlítottuk össze. A két adat hányadosa a $\mathrm{G}_{\text {index }}$. Egyezésnek a $\mathrm{G}_{\text {index }}$ 0,95-1,05 közötti értékeit tartottuk. A 0,95 alatti adatokat alacsony $\mathrm{G}_{\text {index }}$-nek, a 1,05 felettieket magas $\mathrm{G}_{\text {index }}$-nek tekintettük. Ezek a tartományok a ma használt, certifikált $\mathrm{HbA}_{1 \mathrm{c}^{-}}$ mérési módszerek az IFCC által végzett EurAlc-vizsgálat adatainak felelnek meg [14]. Ennél kisebb eltérés a mérési hibahatáron belül van.

\section{A hemoglobinglikáció biokinetikus modellje}

A biokinetikus modell az 1 ábrán látható helyzet matematikai megfogalmazása. Az első egyenlet - $\{1\}-$ a $\mathrm{HbA}_{\mathrm{lc}}$ értékének kiszámítását teszi lehetővé állandó vércukor esetében, a második - $\{2\}$ - a 120 napon belüli, különböző időtartamú és intenzitású hyperglykaemiás időszakokra vonatkozik.

\section{A biokinetikus modell egyenletei}

$$
\begin{aligned}
& \{1\} H b A_{I c}=1-\frac{e^{-t \cdot k \cdot g}}{t \cdot k \cdot g} \\
& \{2\} H b A_{1 c}=\frac{1-\left[\frac{1}{A}+\left(\frac{1}{A}-1+X\right) \cdot Y\right] \cdot Z}{t \cdot k \cdot g}
\end{aligned}
$$

„e" a természetes logaritmus alapja $(2,718) ;$ „k” a kötődés kinetikus konstansa $\left(1,86 \cdot 10^{-4} \mathrm{mmol} \cdot \mathrm{l}^{-1} \cdot \mathrm{nap}^{-1}\right) ;$ "g” a vércukor $\mathrm{mmol} \cdot \mathrm{l}^{-1}$-ben és „t” a vörösvérsejtek élettartama, 120 nap.

A kettes egyenletben „A” a vércukor növekedése az eredeti vércukorhoz képest, $\mathrm{X}=\mathrm{e}^{-\mathrm{k} \cdot \mathrm{g}(120-\mathrm{t} \mathrm{l})} ; \mathrm{Y}=\mathrm{e}^{-\mathrm{k} \cdot \mathrm{g} \cdot \mathrm{A} \cdot(\mathrm{tl}-\mathrm{t} 0)} ; \mathrm{Z}=\mathrm{e}^{-\mathrm{k} \cdot \mathrm{g} \cdot \mathrm{t} 0} ;$ ahol t0 és $\mathrm{tl}$ a hyperglykaemiás időtartam kezdete és vége napokban
4. táblázat |A betegek anyagcserekontrollja

\begin{tabular}{lll}
\hline Mutató & Átlag $\pm \mathrm{SD}$ & Min.-max. \\
\hline Vércukor, mmol.l $\mathrm{l}^{-1}$ & $8,63 \pm 2,10$ & $4,56-15,45$ \\
$\mathrm{HbA}_{\mathrm{lc}}, \mathrm{mmol} \cdot \mathrm{mol}^{-1}$ & $67,3 \pm 15,9$ & $28,7-112,5$ \\
$\mathrm{HbA}_{\mathrm{lc}}, \%$ & $8,30 \pm 1,46$ & $4,75-12,45$ \\
\hline
\end{tabular}

$\mathrm{HbA}_{\mathrm{lc}}=$ hemoglobin- $\mathrm{A}_{\mathrm{lc}}$ (glikált hemoglobin); $\mathrm{SD}=$ standard deviáció

\section{Eredmények}

A vizsgált csoport átlagos vércukra és a mért $\mathrm{HbA}_{\mathrm{lc}}$ értékei az 4. táblázatban szerepelnek, a két mutató összefüggése lineáris regressziós analízis alapján a 2. ábrán látható. Előzetes számításaink eredményei szerint úgy döntöttünk, hogy nem az összes mért vércukor és az összes mért HbAlc közötti összefüggéseket vizsgáljuk, hanem azok átlagát az egyes betegekben.

A $G_{\text {index }}$ értékét (mért/várt $\mathrm{HbA}_{\mathrm{lc}}$ ) kétféle módon számoltuk:

1) a mért $\mathrm{HbA}_{\mathrm{lc}}$ és a 2. ábrán látható regressziós egyenlet alapján és

2) a mért $\mathrm{HbA}_{\mathrm{lc}}$ és az $\{1\}$ egyenlet alapján várt adatok szerint.

A mért és a várt $\mathrm{HbA}_{\mathrm{lc}}$-értékek között egyezést mindössze a vizsgált betegek kevesebb mint egynegyedében (saját regresszió), illetve egyötödödében (biokinetikus modell szerinti regresszió) találtunk, de a magas és az alacsony $\mathrm{G}_{\text {index- }}$ étékek megoszlása a két módszerrel számított adatok alapján jelentősen különbözött (5. táblázat). A további számításokat csak a biokinetikus modell szerint számítottuk, mert a saját egyenletből számított eltérések mindössze az adatok szórását mutatják. A 6. táblázatban talált eredményekkel összhangban van az is, hogy az egész vizsgált csoport átlagos vércukra 8,63 mmol. $\mathrm{l}^{-1}$ (5. táblázat), és ebből az $\{1\}$ egyenlet szerint a $\mathrm{HbA}_{\mathrm{lc}}$ várt átlagértéke $75,8 \mathrm{mmol} \cdot \mathrm{mol}^{-1}$; a ténylegesen mért adatok átlaga ezzel szemben $67,3 \mathrm{mmol} \cdot \mathrm{mol}^{-1}$, ami 0,89 -es $\mathrm{G}_{\text {index }}$-nek felel meg.

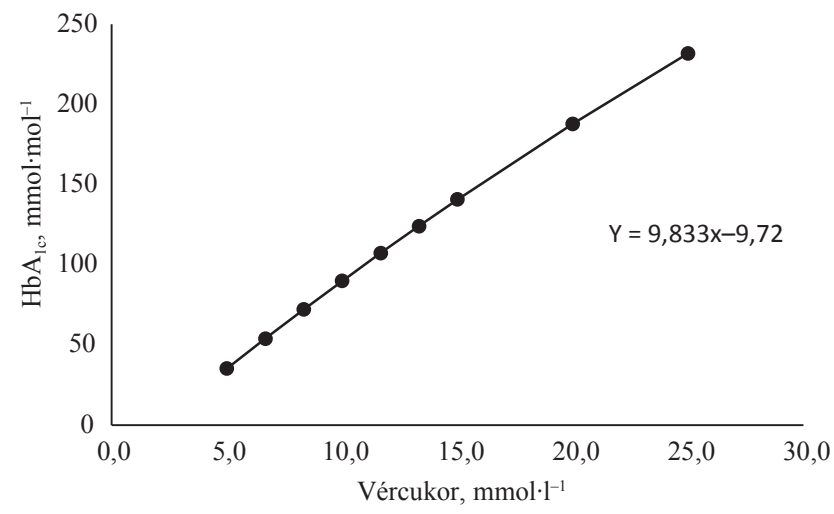

2. ábra $\quad$ Az átlagos vércukor és a $\mathrm{HbA}_{\mathrm{lc}}$ közötti összefüggés a biokineti kus modell $\{1\}$ egyenlete szerint

$\mathrm{HbA}_{1 \mathrm{c}}=$ hemoglobin- $\mathrm{A}_{\mathrm{lc}}$ (glikált hemoglobin $)$ 
5. táblázat | Glikációs index 157, ambulánsan kezelt cukorbetegnél

\begin{tabular}{lcc|cc}
\hline & \multicolumn{2}{c|}{ Saját adatok } & \multicolumn{2}{c}{ Modell } \\
\hline Csoport & $\mathrm{n}$ & $\%$ & $\mathrm{n}$ & $\%$ \\
\hline Alacsony $\mathrm{G}_{\text {index }}(<0,95)$ & 61 & 38,9 & 94 & 59,9 \\
Egyezés $(0,95-1,05)$ & 39 & 24,8 & 30 & 19,1 \\
${\text { Magas } \mathrm{G}_{\text {index }}(>1,05)}$ & 57 & 36,3 & 33 & 21,0 \\
\hline
\end{tabular}

$\mathrm{G}_{\mathrm{index}}=$ glikációs index, a várt és a mért $\mathrm{HbA}_{\mathrm{lc}}$ aránya

6. táblázat |A glikációs index különböző átlagos vércukorértékek szerint felbontásban

\begin{tabular}{lcllll}
\hline $\begin{array}{l}\text { Átlagos } \\
\text { vércukor }\end{array}$ & $\mathrm{n}$ & $\begin{array}{l}\mathrm{G}_{\text {index }} \\
\text { Átlag } \pm \mathrm{SD}\end{array}$ & $\begin{array}{l}\mathrm{G}_{\text {index }} \\
<0,95 \\
\mathrm{n}(\%)\end{array}$ & $\begin{array}{l}\mathrm{G}_{\text {index }} \\
0,95-1,05 \\
\mathrm{n}(\%)\end{array}$ & $\begin{array}{l}\mathrm{G}_{\text {index }} \\
\mathrm{l}, 05 \\
\mathrm{n}(\%)\end{array}$ \\
\hline$<7 \mathrm{mmol} \cdot \mathrm{l}^{-1}$ & 40 & $1,08 \pm 0,19$ & $9(22,5)$ & $9(22,5)$ & $22(55,0)$ \\
$7-10 \mathrm{mmol} \cdot \mathrm{l}^{-1}$ & 72 & $0,90 \pm 0,15$ & $47(65,3)$ & $14(19,4)$ & $11(15,3)$ \\
$>10 \mathrm{mmol} \cdot \mathrm{l}^{-1}$ & 45 & $0,81 \pm 0,12$ & $40(88,9)$ & $3(6,7)$ & $2(4,4)$ \\
\hline
\end{tabular}

Az átlagos glikációs index eredményei az első és a második, valamint az elsó és a harmadik csoport között szignifikánsak p<0,001 szinten, a második és a harmadik között $\mathrm{p}<0,032$ szinten.

$\mathrm{G}_{\mathrm{index}}=$ glikációs index, a várt és a mért $\mathrm{HbA}_{\mathrm{lc}}$ aránya; $\mathrm{SD}=$ standard deviáció

A $\mathrm{G}_{\text {index }}$ vizsgálatának eredményeit a betegek átlagos vércukra szerint a 6. táblázat tartalmazza. Jó anyagcserekontroll mellett a $\mathrm{G}_{\text {index }}$ értéke a legtöbb esetben magasabb volt, mint 1,05, de magas átlagos vércukor (>10 mmol. $1^{-1}$ ) esetében az index értéke a betegek túlnyomó többségében kisebb volt, mint 0,95.

A regressziós egyenletek szerinti analízis eredményei (7. táblázat) alátámasztják azt a nézetet, hogy alacsony átlagos vércukor mellett gyakoribb a mért $\mathrm{HbA}_{\mathrm{lc}}$ vártnál magasabb értéke, mint a biokinetikus egyenlet által számítotté $\left(\mathrm{G}_{\text {index }}>1,05\right)$; magasabb átlagos vércukor esetében ez fordítva van. Egyezés esetén a regressziós egyenlet együtthatói gyakorlatilag azonosak a modell alapján számított értékekkel.

\section{Megbeszélés}

Ma már senki sem vonja kétségbe, hogy az anyagcserekontrollnak meghatározó szerepe van az idült szövődmények patogenezisében $[15,16]$. A jó anyagcserekontroll elérésének négy feltétele van:

1) a lehető leghatásosabb gyógymód helyes alkalmazása;

2) a megfelelő ellátási rendszer hozzáférhetősége minden beteg számára;

3 ) intenzív edukáció;

4) mutatók, amelyek pontos képet adnak az anyagcserekontrollról, és azok helyes értelmezése.

$\mathrm{A} \mathrm{HbA}_{\mathrm{lc}}$ meghatározásának módszerei az elmúlt 50 év alatt sokat fejlődtek [14], de az adatok helyes interpretációja ezzel nem tartott lépést. Ez fóleg akkor jelent
7. táblázat $\mid$ A glikációs index és az átlagos vércukor közötti összefüggés reg ressziós analízis alapján

\begin{tabular}{llll}
\hline Csoport & $\begin{array}{l}\text { Korrelációs } \\
\text { koefficiens } \\
\mathrm{r} ; \mathrm{r}^{2}\end{array}$ & $\begin{array}{l}\text { Meredekség } \\
\mathrm{b}^{\#}\end{array}$ & $\begin{array}{l}\text { Tengelymetszet } \\
\mathrm{a}^{\#}\end{array}$ \\
\hline Teljes csoport & 0,$73 ; 0,55$ & 5,503 & $+19,761$ \\
Modell & & 9,835 & $-9,792$ \\
$\mathrm{G}_{\text {index }} 0,95-1,05$ & 0,$99 ; 0,98$ & 9,740 & $-9,033$ \\
$\mathrm{G}_{\text {index }}<0,95$ & 0,$86 ; 0,55$ & 6,972 & $+0,613$ \\
$\mathrm{G}_{\text {index }}>1,05$ & 0,$88 ; 0,77$ & 10,421 & $-3,504$ \\
\hline
\end{tabular}

*Nincs a 3. ábrán feltüntetve.

\#Az $\mathrm{y}=\mathrm{a}+\mathrm{bx}$ egyenleg együtthatói, ahol y a $\mathrm{HbA}_{\mathrm{lc}}$ és $\mathrm{x}$ a vércukor értéke.

$\mathrm{G}_{\text {index }}=$ glikációs index, a várt és a mért $\mathrm{HbA}_{\mathrm{lc}}$ aránya; $\mathrm{HbA}_{\mathrm{lc}}=$ hemoglobin- $\mathrm{A}_{\mathrm{lc}}$ (glikált hemoglobin)

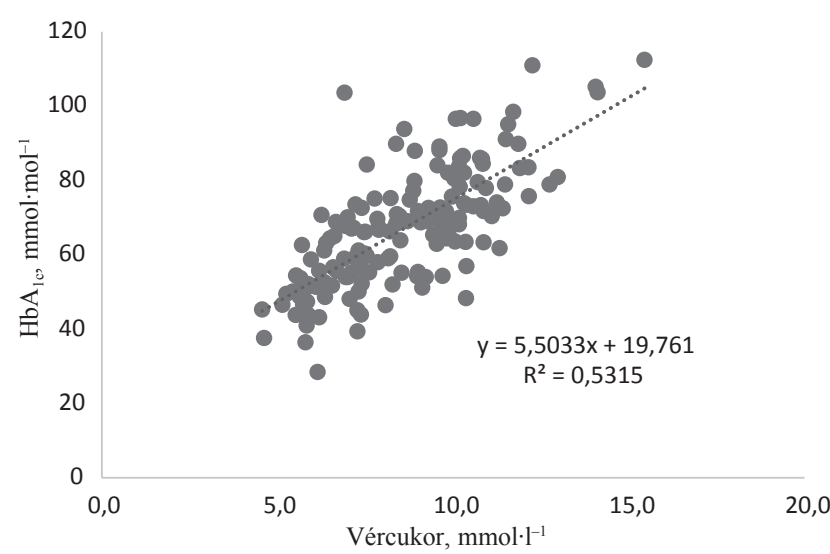

3. ábra

Az átlagos vércukor és a mért $\mathrm{HbA}_{1 \mathrm{c}}$ közötti összefüggés saját adatainkból számolva

$\mathrm{HbA}_{\mathrm{lc}}=$ hemoglobin- $\mathrm{A}_{\mathrm{lc}}$ (glikált hemoglobin)

problémát, ha a $\mathrm{HbA}_{\mathrm{lc}}$ mért értéke nem felel meg a beteg vércukrának. A probléma nem oldódott meg az önellenőrzés és a kontinuális vércukormérés bevezetésével sem [17-20].

A mért és a várt $\mathrm{HbA}_{\mathrm{lc}}$ (vagy a mért és a $\mathrm{HbA}_{\mathrm{lc}}$-ból számolt vércukor - eAG, estimated average glucose) közötti diszkordancia gyakori jelenség, mértékét a Betegek és módszerek fejezetben ismertetett számítások segítségével meg lehet határozni. A legtöbb tanulmány arra is rámutat, hogy a pozitív rés vagy a magas index és az idült szövődmények gyorsabb manifesztációja között összefüggés van. Ezek azonban a saját vizsgált betegcsoport vércukor- és $\mathrm{HbA}_{\mathrm{lc}}$-értékei közötti regressziós analízisből indultak ki, ami annyit jelent, hogy a pozitív vagy negatív eredmények a regressziós egyeneshez viszonyított szórást jelentik. Jelen vizsgálatunkban a glikációs index értékeit vizsgáltuk a biokinetikus modell alapján számolt egyenlet paramétereihez viszonyítva. A saját adatokból és a biokinetikus modellból számított adatok egyértelmúen azt bizonyítják, hogy a mért és a várt $\mathrm{HbA}_{\mathrm{lc}}$ közötti egyezés ritkább, mint a kettő közötti diszkordancia, de jelentős különbség van a két módszer- 
rel számított adatok között (5. táblázat). Véleményünk szerint a valós képet a modell szerinti számítások nyújtják. A vércukor szerint felosztott adatok alapján (6. táblázat) a $\mathrm{G}_{\text {index }}$ átlagértéke és eloszlásuk szignifikánsan eltér a jó, elfogadható és rosszabb anyagcserekontroll esetében. Figyelemre méltó az a tény is, hogy az adatokat felosztva a $\mathrm{G}_{\text {index }}$ szerint a mért és a várt $\mathrm{HbA}_{\mathrm{lc}}$ közötti összefüggés szorosabb, mint az összes adatra számolva, és a 0,95-1,05 közötti csoport regressziós egyenlete gyakorlatilag azonos az elméletivel. A másik két csoport ettől eltérő paraméterei arra utalnak, hogy egy eddig meg nem határozott tényező hatással van a mért $\mathrm{HbA}_{\mathrm{lc}}$ és az átlagos vércukor közötti összefüggésre. A biokinetikus modell erre elméletileg olyan módon tud választ adni, hogy az alacsony index esetén a magasabb vércukorértékek régebben történtek, magas index esetén közvetlenül a $\mathrm{HbA}_{\mathrm{lc}}$ mérése előtt. Ennek bizonyítására sokkal szélesebb és pontosabb adathalmazra lesz szükség, mint amely jelenleg rendelkezésünkre állt.

\section{Következtetés}

Jelen munkánkban arra kerestünk választ, hogy magyarázható-e a mért és a várt $\mathrm{HbA}_{\mathrm{lc}}$ közötti eltérés, amelyet a $\mathrm{G}_{\text {index }}$ formájában lehet meghatározni a glikáció biokinetikus modellje alapján. Vizsgálataink azt mutatják, hogy ez logikus és lehetséges, de nem bizonyított. A mindennapi diabetológiai gyakorlatban valószínúleg a jövőben sem lesz lehetséges az egyes betegek anyagcserekontrollját a biokinetikus modell segítségével meghatározni, de az már most biztos, hogy a kontroll minőségét csak a kapott adatok komplex értékelése alapján lehet megítélni. Ehhez a biokinetikus modell ismerete komoly támpontot jelent.

Anyagi támogatás: A közlemény megírása anyagi támogatásban nem részesült.

Munkamegosztás: R. O.: A csoport vezetője, alapvető gondolatok, számítások, a cikk megírása, a táblázatok és az ábrák előkészítése. B. L.: A munka irányítása és a cikk írása a gyakorló diabetológia szempontjából. E. Gy.: Az óbudai csoport koordinátora. A modellel kapcsolatos számítások végzése, ellenőrzése. K. L.: Az óbudai csoport vezetője. A részeredmények összegezése a két csoport számára. B. M.: Számítások végzése, az ábrák készítése. M. K.: A kézirat végső formájának elkészítése, az adatok ellenőrzése. D. P.: Az eredeti adatok beszerzése, elsődleges feldolgozásuk. A cikk végleges változatát valamennyi szerző elolvasta és jóváhagyta.

Érdekeltségek: A szerzőknek nincsenek érdekeltségeik.

\section{Irodalom}

[1] Lippi G. The irreplaceable value of laboratory diagnostics: four recent tests that have revolutionized clinical practice. EJIFCC 2019; 30: 7-13.

[2] Rácz $\mathrm{O}$. The old and beautiful new world of $\mathrm{HbA}_{1 \mathrm{c}}$. [A HbA $\mathrm{Hb}_{\mathrm{lc}}$ régi és szép új világa.] Diabetol Hung. 2008; 16: 239-248. [Hungarian]

[3] Nathan DM, Turgeon H, Rega S. Relationship between glycated haemoglobin levels and mean glucose levels over time. Diabetologia 2007; 50: 2239-2244.

[4] Beach KW. A theoretical model to predict the behaviour of glycosylated hemoglobin levels. J Theor Biol. 1979; 81: 547-561.

[5] Mortensen HB, Vølund A. Application of a biokinetic model for prediction and assessment of glycated haemoglobins in diabetic patients. Scand J Clin Lab Invest. 1988; 48: 595-602.

[6] Ladyzyński P, Wójcicki JM, Bak M, et al. Validation of hemoglobin glycation models using glycemia monitoring in vivo and culturing erythrocytes in vivo. Ann Biomed Eng. 2008; 36: $1188-1202$.

[7] Rácz O, Vícha T, Pačin J. Glycohemoglobin, glycation of proteins and diabetes mellitus. [Glykohemoglobín, glykácia bielkovín a diabetes mellitus.] Osveta, Martin, 1989. [Slovak]

[8] Advani A. Positioning time in range in diabetes management. Diabetologia 2020; 63: 242-252.

[9] Campbell L, Pepper T, Shipman K. HbAlc: a review of nonglycaemic variables. J Clin Pathol. 2019; 72: 12-19.

[10] Soros AA, Chalew SA, McCarter RJ, et al. Hemoglobin glycation index: a robust measure of hemoglobin Alc bias in pediatric type 1 diabetes patients. Pediatr Diabetes 2010; 11: 455-461.

[11] Rodríguez-Segade S, Rodríguez J, García Lopez JM, et al. Estimation of the glycation gap in diabetic patients with stable glycemic control. Diabetes Care 2012; 35: 2447-2450.

[12] van Steen SC, Schrieks IC, Hoekstra JB, et al. The haemoglobin glycation index as predictor of diabetes-related complications in the AleCardio trial. Eur J Prevent Cardiol. 2017; 24: 858-866.

[13] Hempe JM, Liu S, Myers L, et al. The hemoglobin glycation index identifies subpopulations with harms or benefits from intensive treatment in the ACCORD trial. Diabetes Care 2015; 38: 1064-1074.

[14] EurAlc Trial Group. EurAlc: the European HbAlc Trial to investigate the performance of $\mathrm{HbAlc}$ assays in 2166 laboratories across 17 countries and 24 manufacturers by use of the IFCC model for quality targets. Clin Chem. 2018; 64: 1183-1192.

[15] American Diabetes Association. Introduction: standards of medical Care in diabetes - 2021. Diabetes Care 2021; 44(Suppl 1): S1-S2.

[16] American Diabetes Association. 6. Glycemic targets: standards of medical care in diabetes - 2021. Diabetes Care 2021; 44(Suppl 1): S73-S84.

[17] Chehregosha H, Khamseh ME, Malek M. View beyond HbAlc: Role of continuous glucose monitoring. Diabetes Ther. 2019; 10: 853-863.

[18] Battelino T, Bergenstal RM. Continuous glucose monitoringderived data report - simply a better management tool. Diabetes Care 2020; 43: 2327-2329.

[19] Beck RW, Connor CG, Mullen DM, et al. The fallacy of average: how using $\mathrm{HbA}_{\mathrm{lc}}$ alone to assess glycemic control can be misleading. Diabetes Care 2017; 40: 994-999.

[20] Oriot P, Hermans MP. "Mind the gap please...": estimated vs. measured $\mathrm{A}_{\mathrm{lc}}$ from continuous measurement of interstitial glucose over a 3 -month period in patients with type 1 diabetes. Acta Clin Belg. 2020; 75: 109-115

(Rácz Olivér dr., Kassa-Košice, Trieda SNP 1, Szlovákia e-mail: olliracz@gmail.com)

A cikk a Creative Commons Attribution 4.0 International License (https://creativecommons.org/licenses/by/4.0/) feltételei szerint publikált Open Access közlemény, melynek szellemében a cikk bármilyen médiumban szabadon felhasználható, megosztható és újraközölhető, feltéve, hogy az eredeti szerző és a közlés helye, illetve a CC License linkje és az esetlegesen végrehajtott módosítások feltüntetésre kerülnek. (SID_1) 